\title{
Hereditary Hemochromatosis: A Literature Review and Case Report
}

\author{
Mary K. Allen
}

\section{ABSTRACT}

Purpose: To improve understanding in the physical therapy (PT) community of hereditary hemochromatosis (HH), a common but little-known iron overload disorder, symptoms of which may mimic other orthopaedic conditions. Medical management typically involves phlebotomy to remove excess iron; however, there is little specific information in the literature on PT management of patients with HH after trauma.

Case description: The patient was a 65-year-old woman with multiple fall-related traumas, including right wrist, thumb, and patellar fractures and left thigh muscle strain with significant ecchymosis and effusion. Medical history included $\mathrm{HH}$. Iron-related lab values had been analyzed 9 days prior to the fall and had demonstrated a steady increase over the previous 4 months since her last phlebotomy.

Outcomes: As the level of exercise and activity increased during the course of PT treatment, the patient developed shortness of breath and increased fatigue. The exercise level in therapy was reduced to accommodate the change in the patient's response. Blood values analyzed 7 weeks after the fall demonstrated a drop in haemoglobin and hematocrit values, while serum ferritin levels had risen.

Implications: Understanding early symptoms and management of a patient with manifestations of $\mathrm{HH}$ will better enable physical therapists to consider this disorder as a differential diagnosis or co-morbidity that affects treatment considerations.

Key Words: arthralgia, ferritin, hemochromatosis, hereditary, iron overload, joint

Allen MK. Hereditary hemochromatosis: a literature review and case report. Physiother Can. 2010;62:276-284.

\section{RÉSUMÉ}

Objectif : Améliorer la compréhension de l'hémochromatose héréditaire au sein de la profession de physiothérapeute. L'hémochromatose héréditaire (HH) est un trouble courant mais peu connu, qui provoque une surcharge de fer dans l'organisme et dont les symptômes peuvent s'apparenter à ceux de problèmes de nature orthopédique. La gestion médicale de la HH implique habituellement une phlébotomie visant à retirer la surcharge de fer de l'organisme. II n'existe toutefois dans la documentation que très peu d'information précise sur la gestion en physiothérapie après traumatisme des patients souffrant de $\mathrm{HH}$.

Description du cas : La patiente était une femme de 65 ans ayant souffert de nombreuses blessures à la suite de chutes, notamment au poignet droit et au pouce, de fractures patellaires et d'une blessure au muscle de la cuisse gauche avec ecchymoses et épanchements importants. Le HH faisait partie de ses antécédents médicaux. Des données de mesure du taux de fer dans son organisme avaient été analysées 9 jours avant sa chute et avaient montré une augmentation constante de son taux de fer au cours des 4 mois précédant sa dernière phlébotomie.

Résultats : Avec l'augmentation de la quantité d'exercices et du niveau d'activité de la patiente au cours de ses traitements en physiothérapie, un essoufflement et une fatigue accrue sont apparus. On a réduit la quantité d'exercices de la thérapie pour l'adapter au changement dans la réponse de la patiente. Les valeurs sanguines analysées 7 semaines après la chute ont montré une baisse des taux d'hémoglobine et d'hématocrite, alors que le taux de ferritine sérique avait augmenté.

Répercussions : Comprendre les symptômes précoces et la gestion d'un patient présentant des manifestations de HH aidera le physiothérapeute à mieux prendre en compte ce trouble sanguin en tant que diagnostic différentiel ou comorbidité affectant les facteurs liés au traitement.

Mots clés : arthralgie, articulations, ferritine, hémochromatose, héréditaire, surcharge en fer

The author would like to express her appreciation to the patient for her cooperation with the case study and to Ted Kepros, MPT, for his review of the manuscript. The following were also gracious in their response to questions regarding serum ferritin: Rakesh Mehta, MD, Assistant Professor of Clinical Medicine, Department of Medicine, Division of Hematology/Oncology, Indiana University; and members of the American Society for Clinical Laboratory Science Consumer Information Web site team: Glenn Flodstrom, MS, MT(ASCP), Associate Professor, Allied Health Division, Northern Virginia Community College; Bernadette Rodak, MS, CLSpH(NCA), Professor, Indiana University Clinical Laboratory Science Program; Mary Ann McLane, PhD, CLS(NCA), Professor, Department of Medical Technology, University of Delaware. Bernadette Rodak and Mary Ann McLane also reviewed the manuscript.
The author has no known conflicts of interest to declare.

Mary K. Allen, MPT, MS: Clinical/Research Physical Therapist, Physiotherapy Associates, Hiawatha, lowa, USA.

Address correspondence to Mary K. Allen, Hawkeye Community College, 1501 East Orange Rd., P.0. Box 8015, Waterlo0, IA 50704-8015 USA (current); Physiotherapy Associates, 2166 Blairs Ferry Rd., Hiawatha, IA 52233-7902 USA (at time of study). E-mail: mallen@hawkeyecollege.edu.

DOI:10.3138/physio.62.3.276 
Table 1 Classification Types of Hereditary Hemochromatosis

\begin{tabular}{lll}
\hline Classification & Mutation & Specifics \\
\hline Type I & HFE gene: C282Y and H63D, chromosome 6 & Most common, seen mainly in Caucasians \\
Type II (A and B) juvenile & $\begin{array}{l}\text { A: Hemojuvelin mutation (G3220V), chromosome 1 } \\
\text { B: Mutation of hepcidin, chromosome 19 }\end{array}$ & Onset prior to age 30; can be seen as early as 6 years of age \\
Type III & Transferrin receptor 2 (TfR2), chromosome 7 & Can be seen in any ethnicity \\
Type IV (A and B) & Ferroportin & Requires only one mutated copy; seen mostly in persons of \\
& & African descent \\
Aceruloplasminemia & Ceruloplasmin gene & $\begin{array}{l}\text { Increased iron in pancreas, brain, and retina; elevated } \\
\text { serum ferritin with low transferrin saturation and mild } \\
\text { anaemia }\end{array}$
\end{tabular}

\section{INTRODUCTION}

Hemochromatosis is an iron storage/overload disorder of either primary (genetic) or secondary (acquired) origin. The vast majority of cases are hereditary in origin and are divided into five major categories (see Table 1). ${ }^{1-3}$ Type I, HFE-gene related hereditary hemochromatosis $(\mathrm{HH})$, is the most common, accounting for 90 to $95 \%$ of all cases. Information presented in this report will therefore focus on Type I HH.

Although HH was first described in 1865 by Trousseau, ${ }^{4}$ the HFE gene was not identified until $1996 .{ }^{5}$ The HFE gene is located on chromosome 6 and is responsible for regulating iron in the body by controlling intestinal iron absorption and deposition in the tissues. ${ }^{6}$ To date, there are 20 known mutations of the HFE gene. C282Y and H63D, the two most common mutations, result in excess dietary iron absorption from the intestinal tract and subsequent deposition in the body's tissues, especially the liver, heart, pancreas, pituitary gland, joints, and skin.

Approximately $10 \%$ of Caucasians in Western countries carry one gene for hemochromatosis, and reported $\mathrm{HH}$ prevalence varies from 1.5-3 cases per 1,000 persons $^{7}$ up to 1 case per $200-400$ persons. $^{8}$ A higher frequency is seen in individuals of northern European descent, and Celtic populations are affected most often. $\mathrm{HH}$ can present in other races, but the frequency is much lower than in Caucasian populations.

Although the mutation is inherited and present at birth, most individuals with $\mathrm{HH}$ do not develop signs and symptoms until later in life (men between 30 and 50 years of age, and women after age 50 ). The accumulation of iron in tissues is a slow process, and it can take years for the level to reach the point when symptoms or clinical signs manifest themselves. Menstruation and pregnancy contribute to the loss of iron in women, delaying the onset of symptoms; with the onset of menopause or after hysterectomy, regular loss of iron is diminished, and iron stores build.

Individuals with $\mathrm{HH}$ may be asymptomatic or may present with a variety of general or organ-related signs and symptoms. ${ }^{9}, 10$ Early symptoms that may prompt a physician visit include arthralgia and fatigue. ${ }^{11}$ These general complaints may mimic other conditions, such as arthritis or fibromyalgia, making diagnosis challenging. An international survey of 2,851 $\mathrm{HH}$ patients reported in 1999 found that patients visited an average of 3.5 physicians before the correct diagnosis was made, ${ }^{12}$ with a mean delay of 10 years between symptom onset and correct diagnosis. If the disorder is not detected and treated early, iron continues to accumulate in the organs and tissues, which may lead to arthritis, increased bloodglucose levels, hypothyroidism, and abnormal liver function. Symptoms relate to tissue or organ involvement and may include abdominal pain, heart palpitations, weakness, loss of libido, impotence, hair loss, and cutaneous hyperpigmentation (skin develops a bronze or slategrey coloration). ${ }^{10,11,13}$ Clinical manifestations during advanced stages of the disorder include diabetes mellitus, cirrhosis, congestive heart failure, cardiac arrhythmia, and liver cancer. ${ }^{10,11,13}$

In recent years, awareness of $\mathrm{HH}$ has improved; more patients are asymptomatic when diagnosed. Elevated serum iron levels may be noted on a routine chemistryscreening panel, prompting further investigation. Firstdegree relatives of a patient diagnosed with $\mathrm{HH}^{11}$ are now routinely screened for early detection and management of $\mathrm{HH}$. A high serum transferrin saturation level is the earliest suggestion of hemochromatosis. ${ }^{14}$ Transferrin is a protein that binds iron and transports it in the blood. Transferrin saturation is the preferred initial screening test for $\mathrm{HH}$ and is performed after an overnight fast. If a patient has a transferrin saturation $\geq 45 \%,{ }^{10,11}$ serum ferritin levels should be tested. Ferritin is a protein that binds to iron for storage purposes in the mucosal cells and normally is found in low levels in portal blood; serum ferritin levels are an indication of overall body storage levels of iron and are elevated in patients with $\mathrm{HH}$, especially in association with high transferrin saturation levels and liver disease. Serum ferritin levels elevated $\geq 200 \mathrm{mcg} / \mathrm{L}$ in pre-menopausal 
women, or $\geq 300 \mathrm{mcg} / \mathrm{L}$ in post-menopausal women or in men, are indicative of primary iron overload resulting from $\mathrm{HH}^{11}$ Genotyping to confirm $\mathrm{HH}$ is indicated in patients with evidence of iron overload. Additional testing may be performed to determine the level of tissue/ organ involvement and subsequent treatment needed.

If $\mathrm{HH}$ is diagnosed prior to the development of cirrhosis and other advanced manifestations of the disorder, a normal life span can be expected; thus, early diagnosis is desirable. The treatment of $\mathrm{HH}$ is an individualized schedule of phlebotomies to rid the body of excess iron and maintain normal iron stores. It is important to note that even if $\mathrm{HH}$ is detected prior to symptom onset, tissue or organ changes may already have occurred. Cardiac changes have been noted in asymptomatic patients, even those receiving regular treatment to regulate iron levels. ${ }^{15}$

Physical therapists should be aware of this genetic disorder and its possible impact on physical therapy (PT) diagnosis and treatment. The presentation of this case study stemmed from the realization that many in the medical community had little awareness of $\mathrm{HH}$. Curiosity led to a literature search, which failed to reveal specific answers to questions about serum ferritin and ecchymosis and, in the process, revealed a dearth of information specific to PT management of a patient with $\mathrm{HH}$ after tissue trauma.

Searches were conducted between May 2008 and August 2009, using search engines typically at the disposal of clinical therapists, including PubMed, MEDLINE, OMNI, Medscape, and Advanced Entrez. Medical centres' Web sites, Healthfinder.gov, Google, and WebMD were checked to determine what type of information was available to the public. Search terms used were hereditary hemochromatosis, physical therapy, hemochromatosis, ecchymosis, tissue trauma, serum ferritin, trauma, and exercise in various combinations. Any available links to related articles were followed. A PubMed search related to $\mathrm{HH}$ and heart-rate recovery during exercise found three articles; ${ }^{16-19}$ these were the only sources located drawing a direct link between physical therapy and $\mathrm{HH}$.

This case report relays clinical knowledge about a disorder that may present as an orthopaedic condition in a new patient or may affect the course of treatment in a patient with an established diagnosis. The report outlines how the medical management of $\mathrm{HH}$ can limit a patient's tolerance for physical activity and exercise after trauma-a somewhat unexpected finding based on the $\mathrm{HH}$ diagnosis alone. The patient gave oral and written permission for the use of this information, and the Physiotherapy Associates IRB approved the case study. The decision to present this information as a case report was made retrospective to the discharge of the patient.

\section{CASE DESCRIPTION}

\section{Patient History}

The female patient was diagnosed with $\mathrm{HH}$ in 2001 at age 59, after experiencing joint pain, fatigue, and sensations of heaviness in her chest. Two subsequent tests of serum ferritin levels came back elevated (614.8 and $498 \mathrm{ng} / \mathrm{ml}$; the reference range is $11.0-306.8 \mathrm{ng} / \mathrm{ml})$. She was referred for genetic testing, which revealed that she was heterozygous for the H63D mutation of the HFE gene but negative for the $\mathrm{C} 282 \mathrm{Y}$ mutation. Individuals who are heterozygous for one gene mutation typically do not show clinical symptoms of $\mathrm{HH}$; however, genetic variation can affect the accuracy of direct mutation testing, and variable expressivity and variable penetrance of a mutation can contribute to a heterozygous person's demonstrating symptoms of $\mathrm{HH} \cdot{ }^{20,21}$ Based on the clinical data and the consistent rise in serum ferritin shown by the patient following phlebotomies, her haematologist diagnosed HH. Genetic testing was recommended for direct family members; the patient's daughter was subsequently diagnosed with $\mathrm{HH}$, and treatment was initiated.

Initial frequent phlebotomies were performed to bring the patient's serum ferritin levels below $50 \mathrm{ng} / \mathrm{ml}$. After that goal was reached, complete blood count (CBC) and serum ferritin levels continued to be monitored every 2 months, and a phlebotomy was performed when serum ferritin levels rose above $50 \mathrm{ng} / \mathrm{ml}$. In the fall of 2007, the patient experienced muscle cramps in her legs, abdomen, and chest. Blood values were monitored in late October 2007, and a phlebotomy was performed (see Table 2). Because of the symptoms she had developed, the patient was monitored monthly in November and December 2007, but no phlebotomy was performed at either recheck. The patient returned for a bimonthly recheck with her haematologist in February 2008. Her serum ferritin levels were still within acceptable levels at that time, and no phlebotomy was performed. She was scheduled to return to the haematologist in April 2008.

Nine days after the February monitoring, the patient had a fall as a result of slipping on icy pavement, resulting in trauma. The patient gave the following subjective report of the events that occurred between her fall and the time she started PT. Immediately after the fall she went to the emergency room, where she was diagnosed with a right thumb mallet fracture and collateral ligament sprain, right wrist fracture, and right patellar fracture. The right hand and wrist were immobilized. She also noted significant left hip and posterior/medial thigh pain, but radiographs were negative for fracture. The left thigh was not visually checked. Six days later, the patient saw her family doctor for a follow-up and was referred to a hand therapist for her wrist and thumb injuries. 
Table 2 Chronology of Laboratory Values Prior to and After Injury

\begin{tabular}{lllllllll}
\hline Lab Test & $\begin{array}{l}\text { Reference } \\
\text { Interval }\end{array}$ & Units & Oct 2007 & Nov 2007 & Dec 2007 & Feb 2008 $^{\mathrm{b}}$ & April 2008 $^{\text {June 2008 }}$ \\
\hline RBC & $4.20-5.40$ & $\mathrm{M} / \mu \mathrm{l}$ & 3.99 & 3.52 & $3.59 \uparrow^{\mathrm{c}}$ & $3.84 \uparrow$ & $3.69 \downarrow$ & 3.75 \\
Haemoglobin & $12.0-16.0$ & $\mathrm{~g} / \mathrm{dl}$ & 12.5 & 11.5 & $11.6 \uparrow$ & $12.1 \uparrow$ & $11.7 \downarrow$ & 11.9 \\
Hematocrit & $37.0-47.0$ & $\%$ & 36.5 & 32.6 & $33.6 \uparrow$ & $34.6 \uparrow$ & $33.7 \downarrow$ & 34.0 \\
Ferritin & $10.0-200.0$ & $\mathrm{ng} / \mathrm{ml}$ & 62.7 & 42.2 & $42.4 \uparrow$ & $44.1 \uparrow$ & $54.5 \uparrow$ & 51.2 \\
\hline
\end{tabular}

$\mathrm{RBC}=$ red blood cell count

a Last phlebotomy performed October 25, 2007.

b Injury occurred on February 28, 2008, 9 days after the February laboratory testing.

c Direction of change in values since previous laboratory test.

Table 3 OPTIMAL Scoring on the Difficulty Baseline ${ }^{\mathrm{a}}$ based on $17^{\mathrm{b}}$ Functional Tasks

\begin{tabular}{|c|c|c|c|c|c|c|}
\hline & \multicolumn{6}{|c|}{ Level of Task Difficulty (OPTIMAL Score) } \\
\hline & $\begin{array}{l}\text { Able to do } \\
\text { without any } \\
\text { difficulty } \\
\text { (1) }\end{array}$ & $\begin{array}{l}\text { Able to do } \\
\text { with little } \\
\text { difficulty } \\
\text { (2) }\end{array}$ & $\begin{array}{l}\text { Able to do } \\
\text { with moderate } \\
\text { difficulty } \\
\text { (3) }\end{array}$ & $\begin{array}{l}\text { Able to do } \\
\text { with much } \\
\text { difficulty } \\
\text { (4) }\end{array}$ & $\begin{array}{l}\text { Unable to do } \\
\text { (5) }\end{array}$ & $\begin{array}{l}\text { Difficulty } \\
\text { Baseline } \\
\text { Score }^{\mathrm{e}}\end{array}$ \\
\hline \# of tasks in each group at start of PT & 0 & 0 & 4 & 5 & $8^{c}$ & 72 \\
\hline \# of tasks in each group at time of discharge & 6 & 4 & 2 & 2 & $3^{\mathrm{d}}$ & 48 \\
\hline
\end{tabular}

The patient again noted intense pain and bruising of the left thigh, as well as limited function of the left lower extremity (LE) as a result of the pain. The LE was not visually examined, nor were blood levels checked. "Rest and (give it) time" or "go to PT" were given as options for the left LE. The patient requested a referral to PT.

\section{Examination}

Physical therapy was initiated 1 week after the fall. The left thigh presented with a dark purple area of ecchymosis $(23 \times 19 \mathrm{~cm})$ from the medial groin region distally, with smaller areas noted on the posterior and anterior thigh. Transitional movements were painful; the patient was unable (unwilling) to actively move the leg from the hip during gait or transfers because of pain and weakness. An antalgic gait pattern was present, but the patient ambulated without an assistive device, in part because of the hand fracture. Her husband provided support with gait. The patient needed assistance with transfers and dressing, and her sleep was impaired. Her OPTIMAL score for the Difficulty-Baseline subscale ${ }^{22}$ was 72 (see Table 3). The OPTIMAL (Outpatient Physical Therapy Improvement in Movement Assessment Log, American Physical Therapy Association, Alexandria, VA; used with permission) is a 21-question instrument able to measure small changes in a patient's ability to perform mobility actions related to functional tasks. In this case, four items associated with the upper extremity were marked "not applicable" and eliminated from the score. Therefore, a score of 17 would have indicated that the patient was able to do all listed activities without difficulty, while a score of 85 would have indicated that she was unable to do any of the listed activities.

With passive testing, the patient had $45^{\circ}$ of hip flexion with the knee in extension prior to pain onset. She was unable to single-leg-stand on the left LE. The initial exam was limited because of the patient's obvious pain (4/10 at best with rest on a visual analogue scale, 8/10 at worst with attempted movement). The treatment initiated included soft-tissue mobilization, passive range of motion (PROM), and a home exercise programme to promote knee and hip motion to reduce joint stiffness and pain (see Table 4). Short-term goals were to bear weight for 5 seconds on the left LE in 2-3 weeks, to improve safety and independence with gait, transfers, and dressing; and to perform a left leg raise independently in 1-2 weeks, to improve gait and transfers. Long-term goals were to stand for 15 seconds on the left LE without 
Table 4 Progression of Treatment

\begin{tabular}{|c|c|c|}
\hline Week & In-Clinic Treatment & Home Exercise Programme \\
\hline 1 & $\begin{array}{l}\text { Manual therapy, including patellar mobilization, PROM hip flexion, } \\
\text { abduction, adduction, internal/external rotation, knee flexion/ } \\
\text { extension. Gentle hamstring stretch. Soft-tissue mobilization to } \\
\text { proximal hamstring, groin, adductors, and quadriceps. Recumbent } \\
\text { bike by end of week. }\end{array}$ & $\begin{array}{l}\text { Quad sets, heel slides and hip abduction/external rotation in supine } \\
\text { hook-lying. Short-arc quads }{ }^{\text {a }} \text { added at fourth visit. }\end{array}$ \\
\hline 2 & $\begin{array}{l}\text { Continued with above treatment. Added Total } \mathrm{Gym}^{\mathrm{b}} \text { at level } 3 \text { and } \\
\text { seated gym ball knee flexion for ROM. Gait training on steps to } \\
\text { decrease hip circumduction. }\end{array}$ & $\begin{array}{l}\text { Continue with above. Added supine bridging }{ }^{c} \text { and hip abduction } \\
\text { AROM. }\end{array}$ \\
\hline 3 & $\begin{array}{l}\text { Continued with manual therapy and therapeutic exercise as above; } \\
\text { seated gym ball long-arc quads. }{ }^{\mathrm{d}} \text { An independent gym programme } \\
\text { was trialled, including seated hip abduction, seated knee extension, } \\
\text { seated hamstring curls, and recumbent bike. Balance activities on } \\
\text { suspended platform. }\end{array}$ & $\begin{array}{l}\text { Added heel raises and straight leg raise. Gym programme as } \\
\text { described at left, to be followed as tolerated. }\end{array}$ \\
\hline 4 & $\begin{array}{l}\text { Discontinued manual treatment. Focus on balance and therapeutic } \\
\text { exercise. Added balance board with Total Gym. }\end{array}$ & Added ankle weight with short-arc quads. \\
\hline 5 & $\begin{array}{l}\text { Step-ups, ankle weight with gym ball long-arc quads, hip drops, } \\
\text { unilateral heel raises, standing hamstring curls, single-leg stand, } \\
\text { balance activities on foam pad and suspended platform, band- } \\
\text { resisted standing knee extension, tubing-resisted sidestepping, } \\
\text { and marching in place. }\end{array}$ & $\begin{array}{l}\text { Added standing hamstring curls, standing total knee extension with } \\
\text { band resistance. Increased amount of weight borne by left side with } \\
\text { heel raises. }\end{array}$ \\
\hline 6 & $\begin{array}{l}\text { Noted increased fatigue and shortness of breath in clinic. Rest breaks } \\
\text { added as needed. Increased resistance with therapeutic exercise, } \\
\text { advanced balance challenges. }\end{array}$ & $\begin{array}{l}\text { Added clamshells, }{ }^{\mathrm{e}} \text { resisted hip internal/external rotation with band } \\
\text { resistance. }\end{array}$ \\
\hline 7 & $\begin{array}{l}\text { Refined home exercise programme, progressed with resistance as } \\
\text { tolerated. Ensured patient's independence with home and gym } \\
\text { programme. Re-evaluated for discharge. Functional and objective } \\
\text { goals met. Total visits }=17 \text {. }\end{array}$ & $\begin{array}{l}\text { Advanced clamshells to hip abduction straight-leg raise, small squat } \\
\text { with band-resisted sidestep. Seated hamstring stretch added. }\end{array}$ \\
\hline
\end{tabular}

PROM = Passive range of motion; ROM = range of motion; AROM = active range of motion

${ }^{a}$ Full knee extension in supine, starting with knee flexed over 6- to 8-inch bolster

b Total Gym Fitness, LLC, West Chester, PA

${ }^{c}$ Starting in supine hook-lying, raise hips off supporting surface until in plane with shoulders and knees.

${ }^{d}$ Full knee extension from a seated position, starting with approximately $90^{\circ}$ of knee flexion.

${ }^{\mathrm{e}}$ In side-lying, hips and knees in flexion, raise top knee away from lower knee.

loss of balance, to allow for safety and independence with dressing, gait and, transfers; to resume $3 \times /$ week workouts at a fitness centre; to dress independently; to walk on even surfaces with a normal gait pattern; and to ascend and descend stairs step-over-step.

\section{Intervention}

The patient was seen for PT 3 times per week for 3 weeks, then twice per week for 4 weeks. Initial sessions focused on treatment of the soft-tissue injuries with edema massage and soft-tissue mobilization. PROM of the left knee and hip was performed to maintain joint mobility. Within patient tolerance, additional motion, strength, balance, and proprioception exercises were added (see Table 4). A re-evaluation at 4 weeks revealed weakness in hip extension (3-/5), hip abduction (3/5), and knee flexion (4/5). With passive testing, the patient had $70^{\circ}$ of hip flexion prior to pain onset; she was able to balance on her right leg for 15 seconds and on her left leg for 5 seconds. Pain was reported to be $2 / 10$ at worst. She was able to ascend or descend stairs stepover-step and walk independently, but still needed assistance with LE dressing (pants, shoes, and socks).
Approximately 5 weeks after the start of PT (6 weeks after the fall), it was noted that the patient demonstrated fatigue during her clinical sessions. This was initially attributed to a lingering respiratory illness combined with the fall-related trauma. As the intensity and variety of exercises were increased over the subsequent session, shortness of breath was noted, and more frequent rest breaks were required. Despite reports of fatigue and shortness of breath, the patient continued to demonstrate progress in terms of both improved function and pain reduction. The shortness of breath was a concern, and if the patient had not had a pre-scheduled appointment with her haematologist within a week of symptom development, contact would have been made with her primary-care physician. The direct connection of symptoms to $\mathrm{HH}$ management was not made until the patient saw her haematologist for her regular 2-month followup. This check-up came 7 weeks after the fall and 1 week after the patient had begun to experience fatigue and shortness of breath during clinical activity. A CBC and serum ferritin profile revealed that both haemoglobin and hematocrit levels had dropped since the February profile, even though they had been rising 
steadily since the October phlebotomy, while serum ferritin levels had risen (see Table 2). The haematologist suggested that the patient had experienced enough bleeding into the tissues of her left thigh to drop haemoglobin and hematocrit levels, producing the observed fatigue and shortness of breath. At this time, the patient also reported to her doctor an increase in abdominal, chest, foot, and leg muscle cramps. In response, the haematologist raised her serum ferritin maintenance level to $60 \mathrm{ng} / \mathrm{ml}$. The haematologist also noted that the patient was fortunate to have started PT as soon as she did after her fall.

The patient was seen for two more sessions, for a total of 17 visits. A home exercise programme to assist with progression of strength and balance was established, with rest breaks as needed to manage the shortness of breath and fatigue. The patient also went to a local fitness centre on a regular basis. At discharge, her OPTIMAL Difficulty-Baseline score had improved to 43 (see Table 3). Knee flexion strength had improved to $5 / 5$, hip abduction to $4+/ 5$, and hip extension to $3+/ 5$. Single-leg stand improved to 20 seconds on the right and 15 seconds on the left. She was transferring and dressing independently and had a normal gait pattern on level surfaces.

\section{DISCUSSION}

Iron is one of the best-known minerals needed by the human system for homeostasis. ${ }^{23}$ It is a co-factor for numerous enzymes and plays a vital role in metabolic processes such as respiration; DNA, RNA, and protein synthesis; the formation of myelin; and the development of neuronal dendritic trees. ${ }^{24}$ At the same time, "free iron" has the capacity to participate in oxygen free-radical formation. ${ }^{25}$ Free radicals can cause perioxidation of organelles, including mitochondria, lysosomes, and sarcoplastic membranes; cleave DNA; and impair protein synthesis and cell proliferation. ${ }^{26}$ Cell damage and fibrosis may result. When iron is bound to transferrin, ferritin, or other transport or storage proteins, it is not available to catalyse the formation of free radicals; ${ }^{27}$ in iron-overload patients, however, the capacity of these proteins to bind with iron is overwhelmed, and tissue damage can occur.

Although abundant information on $\mathrm{HH}$ is available in the literature, including known genetic details, impact on organs, and treatment, there is limited specific information relating to PT. A lower heart-rate recovery after supine (but not upright) exercise ${ }^{16}$ and lower peak $\mathrm{O}_{2}$ uptake during exercise ${ }^{17}$ have been reported. However, the aerobic exercise capacity of asymptomatic $\mathrm{HH}$ subjects did not differ from that of controls. ${ }^{19}$

Awareness of $\mathrm{HH}$ among physical therapists is important because this condition is often misdiagnosed in the early stages, because of the general lack of knowledge about the condition among health care practitioners, and because $\mathrm{HH}$ is a common inherited genetic disorder among Caucasians. ${ }^{9}$ Because early symptoms of $\mathrm{HH}$ may mimic other orthopaedic conditions, $\mathrm{HH}$ should be considered as a differential diagnosis. Questions about fatigue levels, changes in libido, impotence, and family history of $\mathrm{HH}$ would be appropriate when evaluating a patient reporting joint pain or fatigue with an insidious onset $^{13}$ or in patients who fail to improve within a reasonable time frame from the start of PT. A physical therapist cannot diagnose hemochromatosis, but a therapist who is aware of the pathophysiology of the disorder can have an informed discussion with a physician when $\mathrm{HH}$ could be a consideration. Early diagnosis is important to avoid the organ damage that occurs in advanced cases. Identification of a patient with $\mathrm{HH}$ enables testing of first-degree family members, which helps to identify $\mathrm{HH}$ prior to the onset of symptoms. Health history in patients with $\mathrm{HH}$ is critical in exposing any secondary conditions resulting from tissue or organ damage. The most common disease manifestation of $\mathrm{HH}$ is cirrhosis. Patients with $\mathrm{HH}$ who develop cirrhosis are at a more than 200-fold risk for developing liver cancer. ${ }^{11}$ Patients with $\mathrm{HH}$ may also present with arthritis, ${ }^{10}$ cardiomyopathy, ${ }^{10}$ diabetes $(30-60 \%),{ }^{10}$ osteopenia $(41 \%),{ }^{28}$ and osteoporosis (25\%). ${ }^{28}$ If these conditions are present, applicable precautions should guide PT treatment decisions.

Men tend to develop $\mathrm{HH}$ earlier in their lifespan because they do not have the natural losses of iron experienced by females during menstruation and pregnancy; this fact has contributed to the misconception that $\mathrm{HH}$ is found only in men. ${ }^{29}$ Menstrual history, number of pregnancies, and menopausal status are important issues in a women's medical history that may affect not only $\mathrm{HH}$ symptom development but also other aspects of health that are relevant to a physical therapist's diagnosis and treatment decisions. Women with $\mathrm{HH}$ are more likely to present with early symptoms of fatigue and increased skin pigmentation, whereas $45 \%$ of men experience impotence or loss of libido. ${ }^{10}$ Clinically, men with $\mathrm{HH}$ have a higher incidence of cirrhosis and diabetes. $^{29}$

Limiting or avoiding foods high in iron and avoiding iron supplements are part of the treatment regime for $\mathrm{HH}$. Because ascorbic acid increases the absorption of iron, vitamin $\mathrm{C}$ supplements should also be avoided, and fruit juices high in vitamin $\mathrm{C}$ should be consumed between rather than with meals. If a patient has hepatic involvement, alcohol intake should also be avoided. Because increased risk of infection is one of the manifestations of $\mathrm{HH},{ }^{30}$ health care professionals must be vigilant when working with postoperative patients or patients with traumatic wounds. Patients with $\mathrm{HH}$ are usually advised to avoid ingesting raw shellfish because of the risk of infection from organisms such as Yersinia enterocolitica and Vibrio vulnificus. ${ }^{30}$ Patients are also more 
susceptible to Y. pseudotuberculosis sepsis and to Listeria monocytogenes meningitis. ${ }^{11}$ Any clinical manifestation of organ damage will need medical management in addition to the $\mathrm{HH}$ treatment.

For the patient in this case study, serum ferritin level was the benchmark for the need for a phlebotomy. It was interesting to note that her serum ferritin level rose after the trauma she experienced. Two factors may be responsible for this change. First, ferritin is an acute-phase reactant; serum levels rise in response to chronic disease, malignancy, and inflammation, even when there is not a rise in total-body iron stores. ${ }^{31}$ Second, in the case of ecchymosis, when the red blood cell breaks down in the course of tissue bleeding, the heme ring degrades and the iron is released; the freed iron, in turn, stimulates the synthesis of ferritin. ${ }^{32}$ In this case, one or both of these factors may have contributed to the rise in serum ferritin.

$\mathrm{HH}$ is a condition of excess iron absorption and deposition in tissues; however, phlebotomy management of a patient's HH may result in haemoglobin and hematocrit levels on the low end or below reference levels. When treating patients with a known diagnosis of $\mathrm{HH}$, understanding at what level their iron-related blood markers are maintained and when their last phlebotomy was performed may aid in determining their exercise tolerance, especially if they have experienced additional blood loss through internal or external bleeding. As in this case study, blood values may not be monitored by an emergency or primary-care physician after injury and may thus remain unknown until the patient's regular haematologist follow-up. In this case, these values were recorded 7 weeks after the injury, so it is not known how low they had actually dropped. At the time of testing, blood values were not lower than the 1-month postphlebotomy recorded values, yet the patient experienced symptoms associated with low serum iron levels. This phenomenon was most likely due to the patient's higher physical activity level post-injury, resulting from PT at a time when her body was undergoing healing from multiple injuries. The patient had exercised at a fitness centre on a regular basis prior to her injury and had not noted similar symptoms.

\section{LIMITATIONS}

This case study had the following limitations: (1) The LE ROM and strength measures taken at the initial evaluation were limited because of the patient's pain level and tissue trauma. (2) The study documents one patient with $\mathrm{HH}$ and her response to trauma; other individuals with $\mathrm{HH}$ who experience trauma may respond differently. (3) The patient had other injuries and symptoms from the fall (neck pain, right patellar fracture) that were treated in PT. These injuries were not considered limiting factors in the patient's functional left LE gains (the patellar frac- ture was small, and the patient was under no restrictions from the physician). To avoid confusion, these treatments have not been described in the case study. The treatment for the right wrist and hand injuries by a certified hand therapist are also not described in the case study; these injuries, however, did affect the patient's ability to use an assistive device or the right wrist and hand for transfers. (4) Access to certain search engines was not available, and therefore research specific to physical therapy and $\mathrm{HH}$ may have been overlooked.

\section{CONCLUSIONS}

Early symptoms of $\mathrm{HH}$ mimic common orthopaedic conditions. Physical therapists should have knowledge of $\mathrm{HH}$ and its signs and symptoms and should remain cognizant of these when evaluating patients with joint pain. Even though body stores of iron are high in patients with $\mathrm{HH}$, medical management of $\mathrm{HH}$ may keep haemoglobin and hematocrit levels at the lower end of normal. Internal or external bleeding may result in a drop in haemoglobin and/or hematocrit levels, and modifications to the exercise prescription may be needed, depending on the patient's tolerance for increased activity. Family and emergency physicians may not alert the haematologist when there has been an injury involving significant ecchymosis; consequently, it may be the role of physical therapists to contact the managing haematologist about the injury at the onset of therapy. The haematologist can then consider whether she or he wishes to monitor the patient more closely, even if symptoms are not present. Symptom onset would also warrant contact.

\section{KEY MESSAGES}

\section{What Is Already Known on This Subject}

$\mathrm{HH}$ is a hereditary iron-overload disorder that may mimic other orthopaedic conditions in the early stages. If $\mathrm{HH}$ is not treated, tissue and organ damage throughout the body may occur.

\section{What This Study Adds}

This case study adds insight into the factors a physical therapist should consider when evaluating a patient with insidious onset of fatigue and joint pain; $\mathrm{HH}$ may be a differential diagnosis. The management of $\mathrm{HH}$ may result in serum iron markers at the lower end or below normal reference levels. Exercise tolerance should be monitored, and interventions may need to be adjusted if symptoms of low serum iron levels, such as fatigue and shortness of breath, develop. Cardiac changes may be present even in asymptomatic patients with $\mathrm{HH}$ who have had regular treatment. 


\section{REFERENCES}

1. Brissot P, Troadec MB, Bardou-Jacquet E, Lan CL, Jouanolie AM, Deugnier Y, et al. Current approach to hemochromatosis. Blood Rev. 2008;22:195-210. doi:10.1016/j.blre.2008.03.001

2. Xu X, Pin S, Gathinji M, Fuchs R, Harris ZL. Aceruloplasminemia: an inherited neurodegenerative disease with impairment of iron homeostasis. Ann NY Acad Sci. 2004;1012:299-305. doi:10.1196/ annals.1306.024

3. Wallace DF, Subramaniam VN. Non-HFE haemochromatosis. World J Gastroenterol. 2007;13:4690-8.

4. Bacon BR, Powell LW, Adams PC, Kresina TF, Hoofnagle JH. Molecular medicine and hemochromatosis: at the crossroads. Gastroenterology. 1999;116:193-207. doi:10.1016/S0016-5085(99)70244-1

5. Feder JN, Gnirke A, Thomas W, Tsuchihashi Z, Ruddy DA, Basava A, et al. A novel MHC class 1-like gene is mutated in patients with hereditary haemochromatosis. Nat Genet. 1996;13:399-408.

6. Tavill AS. Diagnosis and management of hemochromatosis. Hepatology. 2001;33:1321-8. doi:10.1053/jhep.2001.24783

7. Durupt S, Durieu I, Nove-Josserand R, Bencharif L, Rousset H, Vital Durand D. Hereditary hemochromatosis. Rev Med Interne. 2000;21:961-71.

8. O’Reilly FM, Darby C, Fogarty J, Tormey W, Kay EW, Leader M, et al. Screening of patients with iron overload to identify hemochromatosis and porphyria cutanea tarda. Arch Dermatol. 1997;133:1098-101. doi:10.1001/archderm.133.9.1098

9. Borgaonkar MR. Hemochromatosis: more common than you think. Can Fam Physician. 2003;49:36-43.

10. Drobnik J, Schwartz RA. Hemochromatosis [Internet]. eMedicine Metabolic Diseases; 2008 [cited 2009 Aug 5]. Available from: http:// emedicine.medscape.com

11. Sfeir HE, Klachko DM. Hemochromatosis [Internet]. eMedicine Gastroenterology; 2008 [cited 2009 Aug 5]. Available from: http:// emedicine.medscape.com

12. McDonnell SM, Preston BI, Jewell SA, Barton JC, Edwards CQ, Adams PC, et al. A survey of 2,851 patients with hemochromatosis: symptoms and response to treatments. Am J Med. 1999;106:619-24. doi:10.1016/S0002-9343(99)00120-5

13. Witte DL, Crosby WH, Edwards CQ, Fairbanks VF, Mitros FA. Practice guideline development task force of the College of American Pathologists: hereditary hemochromatosis. Clin Chim Acta. 1996;245:139-200.

14. Gochee PA, Powell LW. What's new in hemochromatosis. Curr Opin Hematol. 2001;8:98-104. doi:10.1097/00062752-200103000-00007

15. Shizukuda Y, Bolan CD, Tripodi DJ, Yau YY, Nguyen TT, Botello G, et al. Significance of left atrial contractile function in asymptomatic subjects with hereditary hemochromatosis. Am J Cardiol. 2006;98:954-9. doi:10.1016/j.amjcard.2006.04.040

16. Arena R, Shizukuda Y, Bolan CD, Tripodi DJ, Yau YY, Smith KP, et al. Heart rate recovery is lower following supine exercise in asymptomatic hereditary hemochromatosis subjects compared with healthy controls. J Cardiopulm Research Prev. 2007;27:157-60.
17. Davidsen ES, Liseth K, Omvik P, Hervig T, Gerdts E. Reduced exercise capacity in genetic haemochromatosis. Eur J Cardiovasc Prev Rehabil. 2007;14:470-5. doi:10.1097/HJR.0b013e3280ac151c

18. Shizukuda Y, Bolan CD, Tripodi DJ, Yau YY, Smith KP, Sachdev V, et al. Left ventricular systolic function during stress echocardiography exercise in subjects with asymptomatic hereditary hemochromatosis. Am J Cardiol. 2006;98:694-8. doi:10.1016/j.amjcard.2006.03.055

19. Shizukuda Y, Bolan CD, Tripodi DJ, Yau YY, Smith KP, Arena R, et al. Exercise capacity of cardiac asymptomatic hereditary hemochromatosis subjects. Med Sci Sport Exerc. 2007;39:3-7. doi:10.1249/ 01.mss.0000240323.08406.f3

20. Rosmorduc O, Poupon R, Nion I, Wendum D, Feder J, Bereziat G, et al. Differential HFE allele expression in hemochromatosis heterozygotes. Gastroenterology. 2000;119:1075-86. doi:10.1053/gast.2000.18146

21. Lyon E, Frank EL. Hereditary hemochromatosis since discovery of the HFE gene. Clin Chem. 2001;47:1147-56.

22. Guccione AA, Mielenz TJ, DeVellis RF, Goldstein MS, Freburger JK, Pietrobon R. Development and testing of a self-report instrument to measure actions: outpatient physical therapy improvement in movement assessment log (OPTIMAL). Phys Ther. 2005;85:515-30.

23. MacKenzie EL, Iwasaki K, Tsuji Y. Intracellular iron transport and storage: from molecular mechanisms to health implications. Antioxid Redox Sign. 2008;10:997-1030. doi:10.1089/ars.2007.1893

24. Gerlach M, Ben-Shachar D, Riederer P, Youdim MB. Altered brain metabolism of iron as a cause of neurodegenerative diseases? J Neurochem. 1994;63:793-807.

25. Linn S. DNA damage by iron and hydrogen peroxide in vitro and in vivo. Drug Metab Rev. 1998;30:313-26. doi:10.3109/03602539808996315

26. Galbraith R. Heme oxygenase: who needs it? Proc Soc Exp Biol Med. 1999;222:299-305. doi:10.1046/j.1525-1373.1999.d01-147.x

27. Wang WC, Ahmed N, Hanna M. Non-transferrin-bound iron in longterm transfusion in children with congenital anemias. J Pediatr. 1986;108:552-7. doi:10.1016/S0022-3476(86)80832-0

28. Valenti L, Varenna M, Fracanzani AL, Rossi V, Fargion S, Sinigaglia L. Association between iron overload and osteoporosis in patients with hereditary hemochromatosis. Osteoporos Int. 2008;20:549-55. doi:10.1007/s00198-008-0701-4

29. Moirand R, Adams PC, Bicheler V, Brissot P, Deugnier Y. Clinical features of genetic hemochromatosis in women compared with men. Ann Intern Med. 1997;127:105-10.

30. Beutler E, Hoffbrand AV, Cook JD. Iron deficiency and overload. Hematology. 2003;40:40-61. doi:10.1182/asheducation-2003.1.40

31. Gabay C, Kusher I. Acute phase proteins and other systemic responses to inflammation. N Engl J Med. 1999;340:448-54. doi:10.1056/NEJM199902113400607

32. Nath KA. Heme oxygenase-1: a redoubtable response that limits reperfusion injury in the transplanted adipose liver. J Clin Invest. 1999;104:1485-6. doi:10.1172/JCI8827 


\section{APPENDIX}

Additional information about hemochromatosis is available from the following organizations:

American Hemochromatosis Society, Inc. 777 East Atlantic Avenue, Suite Z-363 Delray Beach, FL 33483-5352 USA

Tel.: 888-655-IRON (4766) or 561-266-9037

Fax: 561-278-0171

E-mail: ahs@emi.net

Web: http://www.americanhs.org/

American Liver Foundation

75 Maiden Lane, Suite 603

New York, NY 10038-4810 USA

Tel.: 800-GO-LIVER (465-4837)

E-mail: info@liverfoundation.org

Web: http://www.liverfoundation.org/
Canadian Hemochromatosis Society

7000 Minoru Blvd., Suite 272

Richmond, BC V6Y $3 Z 5$ Canada

Tel.: 877-BAD-IRON (223-4766)

E-mail: office@toomuchiron.ca

Web: http://www.cdnhemochromatosis.ca

The Hemochromatosis Foundation, Inc.

P.O. Box 8569

Albany, NY 12208 USA

(Please send a self-addressed stamped envelope to receive material)

Tel.: 515-489-0972

Fax: 518-489-0227

Iron Overload Diseases Association, Inc. 433 Westwind Drive

North Palm Beach, FL 33408-5123 USA

Tel.: $561-840-8512$ or $561-840-8513$

Fax: 561-842-9881

E-mail: iod@ironoverload.org

Web: http://www.ironoverlaod.org/ 